\title{
Cytotoxic activities of synthesized curcumin and 3,4-Difluorinated curcumin against HepG2, LU-1 and KB cancer cell lines
}

\author{
Phan Phuoc Hoai Nhan ${ }^{1}$, Pham Thi Bich Van², Phan Dang Quoi Tu ${ }^{3}$, Pham Nguyen Kim Tuyen ${ }^{4}$, \\ Hoang Minh $\mathrm{Hao}^{3, *}$
}

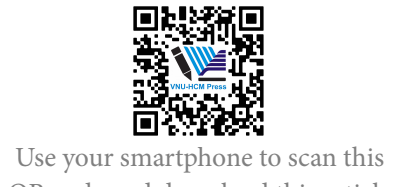

QR code and download this article

\begin{abstract}
Introduction: Natural curcuminoids isolated from turmeric (Curcuma longa L.) have been limited in number and the amount of substrates evaluated in semi-synthetic processes and biological tests. Currently, potent anticancer activities of curcuminoids have garnered increased attention such that a greater number of synthetic procedures of curcumin analogues have been developed for further biological evaluations. The fluorine substituent of fluorinated compounds is important for biological responses. However, natural products bearing fluorine have rarely been found. In the study herein, we employed an aldol condensation between 4-hydroxy-3-methoxybenzaldehyde/3,4difluorobenzaldehyde and pentane-2,4-dione to synthesize the desired curcumin (Cur) and 3,4difluorinated curcumin (3,4-DFCur). Their half-maximal inhibitory concentration $\left(\mathrm{IC}_{50}\right)$ values against HepG2, LU-1 and KB cancer cell lines were then assessed. Methods: Pentane-2,4-dione was converted to enol form by using $\mathrm{B}_{2} \mathrm{O}_{3}$ before carrying out $\mathrm{C}-\mathrm{C}$ coupling reactions with benzaldehyde analogues under basic conditions. The water scavenger was added to the reaction to capture the produced water. The reaction mixture was stirred at $70^{\circ} \mathrm{C}$. The reaction progress was monitored by thin layer chromatography (TLC). Crude products were purified by flash column chromatography (CC; $\mathrm{SiO}_{2}$, eluent: $\left.\mathrm{HEX} / \mathrm{EA}=9 / 1 \rightarrow 7 / 3\right)$. The chemical structures of the desired products were elucidated by ${ }^{1} \mathrm{H},{ }^{13} \mathrm{C}-\mathrm{NMR}, \mathrm{HSQC}$ and MS spectra. The anticancer activities of $\mathbf{C u r}$ and 3,4DFCur against HepG2, LU-1 and KB cancer cell lines were determined using MTT method. Results: Under reasonable reaction conditions, the yields for the coupling reactions were 53 and $72 \%$ for Cur and 3,4-DFCur, respectively. The stable enol tautomer of 1,3-diketone and the trans-configuration in a seven-carbon chain of product skeletons were assigned by ${ }^{1} \mathrm{H}-\mathrm{NMR}$ spectra. All synthesized products showed anticancer activities, with Cur exhibiting higher inhibitory activities when compared with 3,4-DFCur. Cur and 3,4-DFCur are Michael Acceptors; their cytotoxic activities could be attributed to the inhibition of glutathione S-transferase, a detoxification enzyme, by forming glutathionyl adducts. The decreased inhibitory capacities of 3,4-DFCur were due to the effect of fluorine which results in the unfavorable formation of reactive radicals and an increase in lipophilicity. Conclusions: Curcumin and 3,4-difluorinated curcumin were completely synthesized in 53\% and $72 \%$ yields. The synthetic procedure is applicable for synthesizing curcumin derivatives bearing various substituents on the aromatic rings, i.e., not limited to methoxy $\left(-\mathrm{OCH}_{3}\right)$ and hydroxy $(-$ $\mathrm{OH}$ ) groups. Unexpectedly, the presence of fluorines in 3,4-DFCur led to lower cytotoxic activities against cancer cell lines. Our results provide greater insight on the structure-activity relationship of curcumin analogues against cancer cell lines.
\end{abstract}

Key words: Curcumin synthesis, anticancer activity, HepG2, LU-1, KB cancer cell lines, fluorine effect

\section{INTRODUCTION}

Cancer is a major public health problem worldwide and mortality rates from cancer have remained at the maximal peak ${ }^{1}$. There have been some success of chemotherapeutic drugs for treating cancer patients. However, the side effects from such medications have been reported numerous times in literature, and the impact from these medications can be severe and lifethreatening. In order to explore drugs with more efficient properties yet fewer side effects, current research studies have focused on bioactive compounds found in plants as alternative treatments for cancer. Interestingly, curcumin (Cur), a ingredient isolated from turmeric (Curcuma longa L.), was studied as early as the 1940s. This polyphenol was shown to have anti-inflammatory, antioxidant and wound-healing effects.

Recent studies have shown that curcumin may be a potential anticancer agent ${ }^{2-8}$. Experimental findings on curcumin and pharmacophore modeling of its structure have revealed the substituents on Dev. J.; 23(4):786-792. 
phenol rings that are responsible for biological responses $^{1,9-12}$. In order to explore novel curcumin analogues bearing various substituents, i.e., those not limited to methoxy $\left(-\mathrm{OCH}_{3}\right)$ and hydroxy $(-\mathrm{OH})$ groups, a complete synthetic procedure of curcuminrelated compounds was invented. Under basic condition, benzaldehyde derivatives were used as the starting materials to condense with pentane-2,4-dione to yield the desired curcuminoids $5,13,14$.

The effects of the fluorine substituent in molecules on the biological activities of those molecules are important and have been highlighted in previous literature ${ }^{15,16}$. The responses can originate from alterations of the physicochemical properties, such as hydrogen bonding, and electronic properties of the fluorinated molecules.

In this study, we selected 4-hydroxy-3methoxybenzaldehyde and 3,4-difluorobenzaldehyde as starting materials to generate $\mathrm{C}-\mathrm{C}$ coupling reactions with pentane-2,4-dione in order to synthesize the desired curcumin and 3,4-difluorinated curcumin (3,4-DFCur) (Figure 1). Furthermore, in order to explore candidates (such as curcumin) with potential anticancer potencies, the cytotoxicity of those candidate agents were evaluated against human liver cancer (HepG2), lung cancer (LU-1), and human oral epidermal carcinoma (KB) cell lines. In these assays, the cytotoxicity of 3,4-DFCur was compared to that of Cur.

\section{METHODS}

\section{Analytical methods}

The chemical structures of Cur and 3,4-DFCur were elucidated by nuclear magnetic resonance (NMR) spectra, which were recorded on a Bruker Avance system $\left(500 \mathrm{MHz}\left({ }^{1} \mathrm{H}\right), 125 \mathrm{MHz}\left({ }^{13} \mathrm{C}\right)\right)$. Mass spectrometry (MS) measurements were performed on an AGILENT 1200 series LC-MSD machine. The abbreviations of $s$ (singlet), brs (broad singlet), $d$ (doublet), $d d$ (doublet of doublet), $t d$ (triplet of doublet), $d t$ (doublet of triplet), $t$ (triplet) and $m$ (multiplet) were used to represent the patterns of the proton and carbon signals. The desired products were monitored and purified by using thin layer chromatograph (TLC; silica gel 60 F254; Merck) and flash column chromatography (CC; silica gel 0.035-0.070 mm; Merck). Sample spots on TLC were detected by UV light at $\lambda=254$ and $366 \mathrm{~nm}$. M5000 melting point meter (A. KRUSS, Germany) was used to measure the melting points of pure products with a heating rate of $2.0^{\circ} \mathrm{C} / \mathrm{min}$.

\section{Synthetic procedure for Cur and 3,4-DFCur}

Cur and 3,4-DFCur were synthesized according to a published procedure from literature ${ }^{13,14}$. Pentane2,4-dione (10.0 $\mathrm{mmol}$ ) and boron oxide (10.0 mmol) were charged into a $100-\mathrm{mL}$ two-neck round-bottom flask and stirred in ethyl acetate $(20.0 \mathrm{~mL})$ at $70{ }^{\circ} \mathrm{C}$ for $45 \mathrm{~min}$. The starting material- of 4-hydroxy-3-methoxybenzaldehyde $(20.0 \mathrm{mmol})$ or 3,4-difluorobenzaldehyde (20.0 mmol)- and tri- $n$ butyl borate $(40.0 \mathrm{mmol})$ were added together. The mixture reaction was stirred for $30 \mathrm{~min}$ to dissolve the aldehyde reactant before slowly adding $n$-butylamine (4.0 mmol) over $30 \mathrm{~min}$ into a solution via syringe. After completely adding the catalyst, the reaction was stirred at $70^{\circ} \mathrm{C}$ for $4-4.5 \mathrm{hrs}$. The reaction conversion was monitored by TLC. Finally, $20.0 \mathrm{~mL}$ of $\mathrm{HCl}$ solution $(0.1 \mathrm{~N})$ was added and stirred for $1 \mathrm{hr}$. The resulting mixture was extracted with DCM $(3 \times 40 \mathrm{~mL})$. The combined organic phase was dried over $\mathrm{Na}_{2} \mathrm{SO}_{4}$ and the solvent was removed under reduced pressure. The crude product was purified by flash CC $\left(\mathrm{SiO}_{2}\right.$, eluent: $\mathrm{HEX} / \mathrm{EA}=9 / 1 \rightarrow 7 / 3)$.

\section{Cytotoxic assay}

Cur and 3,4-DFCur were tested in vitro for their cytotoxic activities against HepG2, LU-1 and KB cancer cell lines. The procedure was carried out by a modified MTT (3-(4,5-dimethylthiazol-2yl)-2,5-diphenyltetrazolium bromide (MTT) (SigmaAldrich, St. Louis, MO, USA) method ${ }^{17-19}$. HepG2 (HB-8065 $\left.5^{T M}\right)$, LU-1 (HTB-57 $\left.7^{T M}\right)$, and KB $\left(\mathrm{CCL}-17^{T M}\right.$ ) cell lines were obtained from ATCC (Manassas, VA, USA) and seeded in DMEM (Dulbeccos Modified Eagle Medium) (Sigma-Aldrich), supplemented with 10\% FBS (Fetal Bovine Serum) (Sigma-Aldrich) and the other components (1\% glutamine, 1\% Penicillin and Streptomycin, SigmaAldrich). Cells were incubated in a humidified incubator $\left(37^{\circ} \mathrm{C} / 5 \% \mathrm{CO}_{2}\right)$. Ellipticine $(0.01 \mathrm{M})$ was used as a positive control. All samples were completely dissolved in $10 \%$ dimethyl sulfoxide (DMSO) (SigmaAldrich) in medium. The appropriate concentration (190 $\mu \mathrm{L}$ volume) of growing cells was added to each well of the $96-$ well plate. Sample solutions $(10 \mu \mathrm{L}$ volume) were applied to culture wells to yield five final concentrations of $128,32,8,2$ and $0.5 \mu \mathrm{g} / \mathrm{mL}$ in the wells. Each concentration was tested in three separate wells of a 96-well plate, and performed in triplicate. The cultures were incubated for 72 hours at 37 ${ }^{\circ} \mathrm{C}$. Next, MTT $(10 \mu \mathrm{L}, 5 \mathrm{mg} / \mathrm{mL})$ was added to the wells. After 4 hours of incubation at $37^{\circ} \mathrm{C}$ and subsequent removal of $210 \mu \mathrm{L}$ of culture medium from 


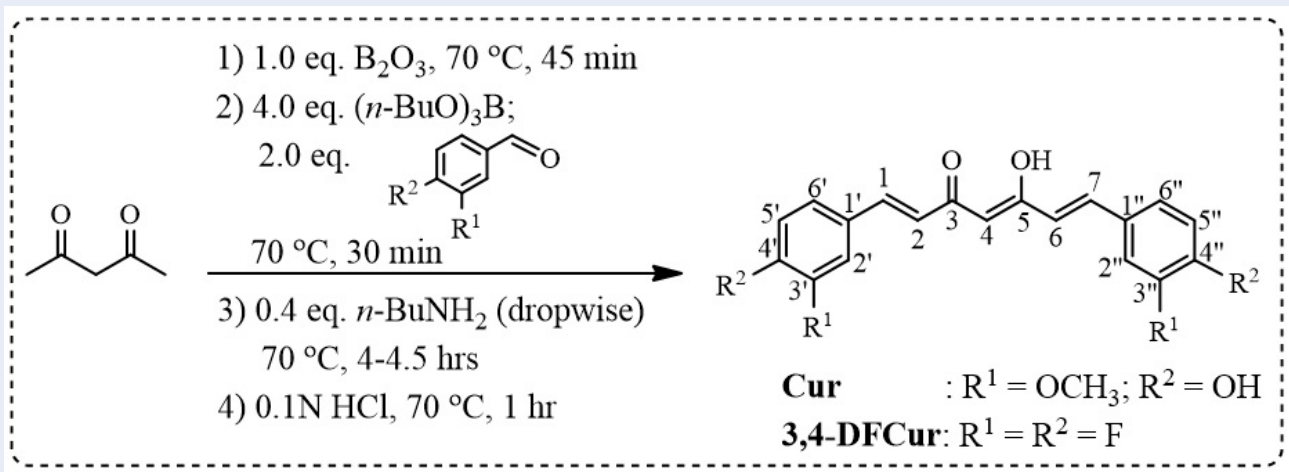

Figure 1: The synthetic procedure of curcumin (Cur) and 3,4-difluorinated curcumin (3,4-DFCur).

each well, the formazan product was dissolved in 100 $\mu \mathrm{L}$ of DMSO. The optical density (OD) at $540 \mathrm{~nm}$ was measured with a BioTek microplate reader (Winooski, Vermont, USA).

The percent inhibition I (\%) of inhibitory activity (see the Supporting Information for the I (\%) values at various concentrations) was calculated using equation (1):

$$
I(\%)=\frac{O D_{\text {with cells }}-O D_{\text {sample }}}{O D_{\text {with cells }}-O D_{\text {without cells }}} \times 100 \%
$$

The $\mathrm{IC}_{50}$ (the half-maximal inhibitory concentration) was calculated by equation (2):

$$
\begin{aligned}
& I C_{50}=\text { High }_{\text {Conc }} \\
& -\frac{\left(\text { High }_{\text {Inh\% }}-50\right) \times\left(\text { High }_{\text {Conc }}-\text { Low }_{\text {Conc }}\right)}{\text { High }_{\text {Inh } \%}-\text { Low }_{\text {Inh }}}
\end{aligned}
$$

Where High Conc and Low Conc are high and low concentrations of samples, respectively. $H_{i g h}$ Inh\% and Low $_{\text {Inh\% }}$ refer to percent inhibition I (\%) at High Conc and Low Conc.

In our assay, one compound was considered as inactive if its $\mathrm{IC}_{50}(\mu \mathrm{g} / \mathrm{mL})$ value was $>128 \mu \mathrm{g} / \mathrm{mL}$. Herein, the $\mathrm{IC}_{50}$ values of the tested compounds were presented in $\mu \mathrm{M}$. TableCurve $2 \mathrm{D}$ was used as a statistical software to analyze data (Systat Software Inc).

\section{RESULTS}

Following published protocols, the desired Cur and 3,4-DFCur agents were synthesized in moderate yields by treatment of 4-hydroxy-3methoxybenzaldehyde or 3,4-difluorobenzaldehyde with pentane-2,4-dione in the presence of boron oxide, $n$-butylamine, and tri- $n$-butyl borate in ethyl acetate at $70^{\circ} \mathrm{C}$ for $4-4.5$ hours (Table 1 ). The isolated yields and the half-maximal inhibitory concentration $\left(\mathrm{IC}_{50}, \mu \mathrm{M}\right)$ values of the derivatives and their in vitro anticancer activities against HepG2, LU-1, and KB cancer cell lines are presented in Table 1 . The $\mathrm{IC}_{50}$ values are expressed as mean \pm standard deviation (SD) of results from three replicates. The chemical structures of Cur and 3,4-DFCur were elucidated on the basis of results from ${ }^{1} \mathrm{H},{ }^{13} \mathrm{C}-\mathrm{NMR}$, HSQC and MS data (see the Supporting Information for spectra).

Cur: Yield 53\% (1.95 g), red-orange solid, $\mathrm{C}_{21} \mathrm{H}_{20} \mathrm{O}_{6}$ [368.13 g/mol]; $R_{f}=0.31$ (HEX/EA = 3/2); m.p. $182.3{ }^{\circ} \mathrm{C} ;{ }^{1} \mathrm{H}-\mathrm{NMR}\left(500 \mathrm{MHz}, \mathrm{CDCl}_{3}\right): \delta=3.96(s$, $\left.\mathrm{OCH}_{3}, 3 \mathrm{H}\right), 3.95\left(s, \mathrm{OCH}_{3}, 3 \mathrm{H}\right), 6.42\left(s, \mathrm{H}_{4}, 1 \mathrm{H}\right)$, $6.83\left(d, \mathrm{H}_{1},{ }^{3} J(\mathrm{H}, \mathrm{H})=16.0 \mathrm{~Hz}, 1 \mathrm{H}\right) ; 6.93\left(d, \mathrm{H}_{5^{\prime}},{ }^{3} J\right.$ $(\mathrm{H}, \mathrm{H})=8.0 \mathrm{~Hz}, 1 \mathrm{H}), 6.94\left(d, \mathrm{H}_{5^{\prime \prime}},{ }^{3} J(\mathrm{H}, \mathrm{H})=8.0 \mathrm{~Hz}\right.$, $1 \mathrm{H}), 6.99\left(d, \mathrm{H}_{7},{ }^{3} J(\mathrm{H}, \mathrm{H})=16.5 \mathrm{~Hz}, 1 \mathrm{H}\right), 7.02-7.08$ $\left(\mathrm{H}_{2^{\prime}, 2^{\prime \prime}, 6^{\prime}, 6^{\prime \prime}}, 4 \mathrm{H}\right), 7.11\left(d, \mathrm{H}_{2},{ }^{3} J(\mathrm{H}, \mathrm{H})=16.5 \mathrm{~Hz}, 1 \mathrm{H}\right)$, $7.29\left(d, \mathrm{H}_{6},{ }^{3} J(\mathrm{H}, \mathrm{H})=16.5 \mathrm{~Hz}, 1 \mathrm{H}\right) \mathrm{ppm} .{ }^{13} \mathrm{C}-\mathrm{NMR}$ $\left(125 \mathrm{MHz}, \mathrm{CDCl}_{3}\right): \delta=55.9\left(\mathrm{OCH}_{3}\right), 55.9\left(\mathrm{OCH}_{3}\right)$, $97.6\left(\mathrm{C}_{4}\right), 108.2\left(\mathrm{C}_{2^{\prime}}\right), 108.8\left(\mathrm{C}_{2^{\prime \prime}}\right), 110.9\left(\mathrm{C}_{5^{\prime}}\right), 113.8$ $\left(\mathrm{C}_{5^{\prime \prime}}\right), 114.6\left(\mathrm{C}_{6^{\prime}}\right), 114.8\left(\mathrm{C}_{6^{\prime \prime}}\right), 121.5\left(\mathrm{C}_{2}\right), 121.6\left(\mathrm{C}_{6}\right)$, $128.2\left(\mathrm{C}_{1^{\prime}}\right), 128.5\left(\mathrm{C}_{1^{\prime \prime}}\right), 134.8\left(\mathrm{C}_{1}\right), 135.6\left(\mathrm{C}_{7}\right), 146.7-$ $146.9\left(2 \mathrm{C}_{4^{\prime}, 4^{\prime \prime}}, 2 \mathrm{C}_{3^{\prime}, 3^{\prime \prime}}\right), 162.1\left(\mathrm{C}_{5}\right), 168.5\left(\mathrm{C}_{4}\right) \mathrm{ppm}$. ESI-MS $m / z$ calc for $[\mathrm{M}+\mathrm{H}]^{+}: 369.14$; found: 368.90 . 3,4-DFCur: Yield 72\% (2.50 g), yellow solid, $\mathrm{C}_{19} \mathrm{H}_{12} \mathrm{~F}_{4} \mathrm{O}_{2}$ [348.08 g/mol]; $R_{f}=0.48(\mathrm{HEX} / \mathrm{EA}=$ 95/5); m.p. $212.3{ }^{\circ} \mathrm{C} ;{ }^{1} \mathrm{H}-\mathrm{NMR}\left(500 \mathrm{MHz}, \mathrm{CDCl}_{3}\right)$ : $\delta=5.81\left(s, \mathrm{H}_{4}, 1 \mathrm{H}\right), 6.52\left(d, \mathrm{H}_{2,6},{ }^{3} \mathrm{~J}(\mathrm{H}, \mathrm{H})=16.0\right.$ $\mathrm{Hz}, 2 \mathrm{H}) ; 7.19\left(m, \mathrm{H}_{5^{\prime}, 5^{\prime \prime}}, 2 \mathrm{H}\right), 7.27\left(m, \mathrm{H}_{2^{\prime}}, 2^{\prime \prime}, 2 \mathrm{H}\right)$, $7.37\left(m, \mathrm{H}_{6^{\prime}}, 6^{\prime \prime}, 2 \mathrm{H}\right), 7.57\left(d, \mathrm{H}_{1,7},{ }^{3} J(\mathrm{H}, \mathrm{H})=16.0 \mathrm{~Hz}\right.$, $2 \mathrm{H}) \mathrm{ppm} ;{ }^{13} \mathrm{C}-\mathrm{NMR}\left(125 \mathrm{MHz}, \mathrm{CDCl}_{3}\right): \delta=102.1$ $\left(\mathrm{C}_{4}\right), 116.1-117.9\left(\mathrm{C}_{5^{\prime}, 5^{\prime \prime}}, \mathrm{C}_{6^{\prime}, 6^{\prime \prime}}\right), 124.9\left(\mathrm{C}_{2,6}\right), 124.9$ $\left(\mathrm{C}_{2^{\prime}, 2^{\prime \prime}}\right), 132.2\left(\mathrm{C}_{1^{\prime}, 1^{\prime \prime}}\right), 138.5\left(\mathrm{C}_{1,7}\right), 150.6\left(d, \mathrm{C}_{4^{\prime}},{ }^{1} \mathrm{~J}\right.$ $(\mathrm{C}, \mathrm{F})=247.5 \mathrm{~Hz}), 150.7\left(d, \mathrm{C}_{4^{\prime \prime}},{ }^{1} J(\mathrm{C}, \mathrm{F})=248.7 \mathrm{~Hz}\right)$, $151.3\left(d, \mathrm{C}_{3^{\prime}},{ }^{1} J(\mathrm{C}, \mathrm{F})=251.2 \mathrm{~Hz}\right), 151.4\left(d, \mathrm{C}_{3^{\prime \prime}},{ }^{1} \mathrm{~J}\right.$ $(\mathrm{C}, \mathrm{F})=251.2 \mathrm{~Hz}), 182.8\left(\mathrm{C}_{3,5}\right) \mathrm{ppm}$; ESI-MS $m / z$ calc for $[\mathrm{M}+\mathrm{H}]^{+}:$349.09; found: 348.80 . 
Table 1: Isolated yields, reaction time and IC 50 values (against HepG2, LU-1 and KB cancer cell lines) of Cur and 3,4-DFCur.

\begin{tabular}{|c|c|c|c|c|c|}
\hline \multirow[t]{2}{*}{ Compound } & \multirow[t]{2}{*}{ Yield (\%) } & \multirow[t]{2}{*}{ Time (hr) } & \multicolumn{3}{|c|}{$\mathbf{I C}_{50} \pm \mathbf{S D}^{[b]}(\mu \mathbf{M})$} \\
\hline & & & HepG2 & LU-1 & KB \\
\hline Cur & 53 & 4.5 & $35.47 \pm 2.77$ & $72.88 \pm 6.19$ & $33.35 \pm 2.66$ \\
\hline 3,4-DFCur & 72 & 4.0 & $42.69 \pm 3.56$ & $305.04 \pm 24.50$ & $66.36 \pm 5.80$ \\
\hline Ellipticine $^{[a]}$ & & & $1.46 \pm 0.12$ & $1.42 \pm 0.12$ & $1.30 \pm 0.12$ \\
\hline
\end{tabular}

${ }^{[a]}$ Ellipticine was used as a positive control. ${ }^{[b]}$ MTT viability assay after $72 \mathrm{~h}, \mathrm{n}=9$, mean $\pm \mathrm{SD}$.

\section{DISCUSSION}

\section{Chemistry}

The reaction conditions- including solvent, catalyst, reaction time, complexing agent, water scavenger and temperature- play crucial roles on the synthetic yields of $\mathrm{C}$ - $\mathrm{C}$ coupling reactions between benzaldehyde analogues and pentane-2,4-dione, in the generation of Cur and 3,4-DFCur ${ }^{13,14}$. The proposed mechanism of aldol condensation under basic condition was depicted in Figure 2. Firstly, in order to form the desired products, $n$-butylamine was selected as a basic catalyst to deprotonate the acidic methyl groups of pentane2,4-dione. However, under basic condition, the 1,3diketone moiety can undergo Knoevenagel condensation with aldehyde. Therefore, it was necessary to convert the 1,3-diketone form to an enolic structure. Boron oxide served as a complexing agent to form an enol configuration by complexing 1,3-diketone with boron. To minimize side reactions, the total amount of catalyst should be $40 \mathrm{~mol} \%$ of 1,3-diketone, and the ratio of 2:1 for aldehyde and pentane-2,4-dione was employed. The formation of water in the reaction would reduce the yield. In order to avoid this, it was important to add a water scavenger to the reaction mixture.

Thus, tri- $n$-butyl borate was used as a water scavenger since it is an ester that would reduce water concentration via hydrolysis reaction. The reaction mixtures were stirred in ethyl acetate (as solvent) at 70 ${ }^{\circ} \mathrm{C}$ and, finally, the boron-Cur/3,4-DFCur complexes were cleaved by addition of a hydrochloric solution to generate the desired products.

The nature of substituents on the aromatic rings of benzaldehyde analogues affected the product yields (Table 1). The electrophilic carbon atom of the aldehyde group was attacked by an enolate as nucleophile. The presence of hydroxy group (-OH), an electrondonating group at para-position in the aromatic ring, gave lower isolated yield (Cur: 53\%). Conversely, a higher yield (3,4-DFCur: $72 \%$ ) was observed when fluorinated aromatic aldehyde was used as the starting material. The results suggested that electronegative fluorine atoms withdraw electron density from the ring. As a result, the attack of an enolate on the carbonyl group is more accessible.

The singlet signal at $\delta(\mathrm{ppm}) 6.42$ of Cur or 5.81 of 3,4-DFCur was assigned as a signal of proton bonded to the central carbon of a $\beta$-diketone. This observation indicated that the final products appeared as enol forms. In addition, two doublet signals were found in the range of 6.5 to $7.8 \mathrm{ppm}$, with coupling constants $\left({ }^{3} J_{H-H}\right)$ of $\sim 16 \mathrm{~Hz}$, which characterize a resonance range of olefinic protons and pairs of trans-isomers. These results revealed trans-configuration in a sevencarbon chain of the curcumin skeleton.

\section{In vitro cytotoxic activities}

As summarized in Table 1, both Cur and 3,4-DFCur showed anticancer activities against HepG2, LU-1 and $\mathrm{KB}$ cancer cell lines, with Cur exhibiting better activity compared to 3,4-DFCur. The lower activity of the fluorinated analogue indicated that the electron-withdrawing substituent in the structure made a negative contribution to its inhibitory response. Among several potential mechanisms regarding the ability of the cytotoxic activity of Cur, its ability to inhibit Phase 2 detoxification enzymes, such as glutathione S-transferases (GST), has received much attention ${ }^{3,20,21}$. Due to the electrophilic $\alpha, \beta$ unsaturated ketone motif, Cur and 3,4-DFCur serve as Michael acceptors which can react with nucleophilic -SH groups of GST and glutathione (GSH) to form glutathionyl adducts. In other words, the enzyme-mediated detoxification was inhibited and cell death was observed.

The anticancer activity of Cur correlated closely with the formation of reactive oxygen species (ROS) ${ }^{8,22-24}$. The phenolic group of Cur can be abstracted $\mathrm{H}$-atom to generate a phenoxyl radical which is stabilized by conjugation with adjacent electrons. The higher anticancer capacity of Cur may be attributed to the presence of para-substituted -OH group in the aromatic 


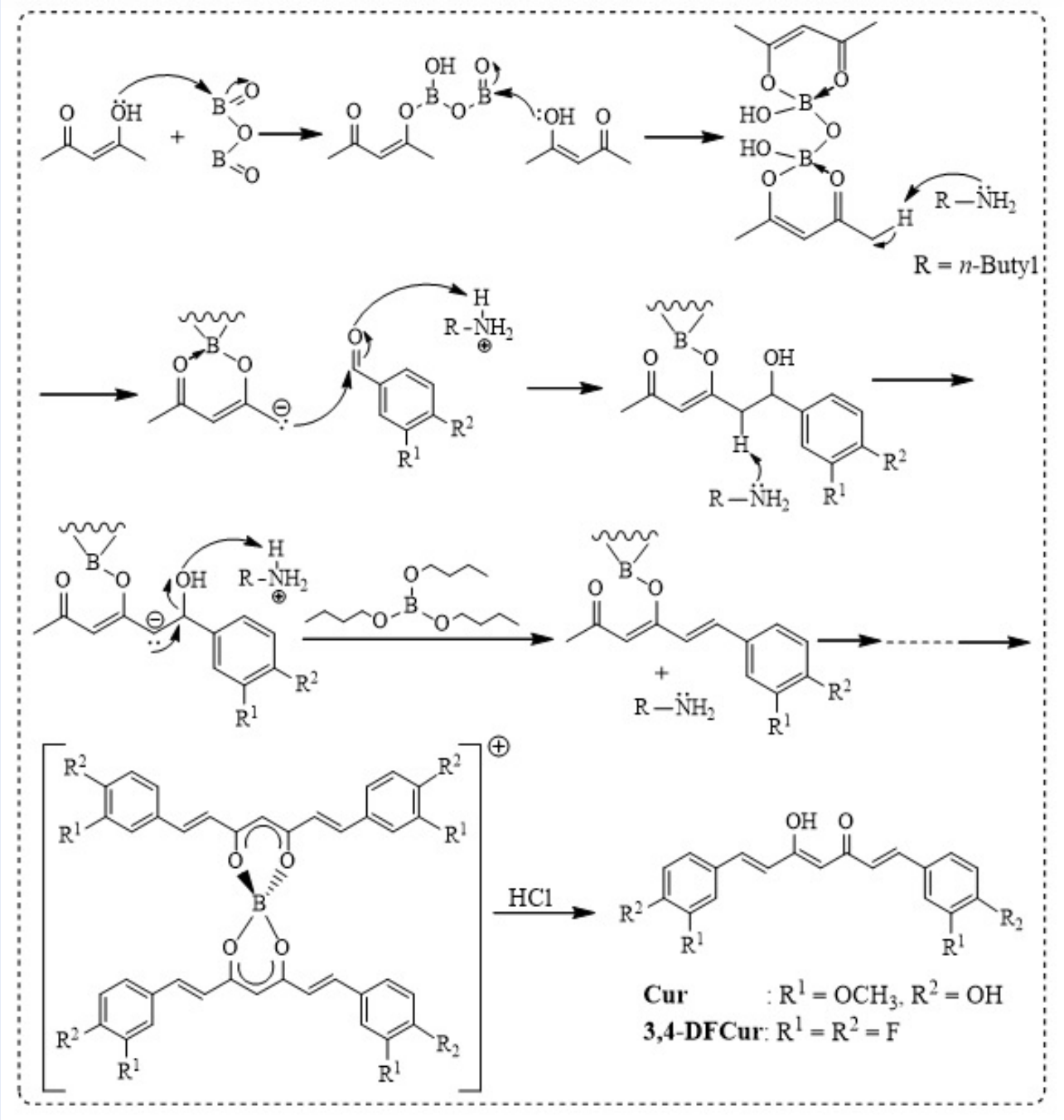

Figure 2: Proposed mechanism for the synthetic procedures of curcumin (Cur) and 3,4-difluorinated curcumin (3,4-DFCur) using aldol condensation between benzaldehyde analogues and pentane-2,4-dione under basic catalyst.

ring which results in the phenoxyl radical being involved in cell apoptosis. The replacement of fluorine atoms in the aromatic rings (3,4-DFCur) led to lower inhibitory activities compared with Cur. Our observations suggest that the fluorination caused the alterations on the electronic properties of curcumin structure. As mentioned, the phenolic motif is crucial for cell death. However, the formation of radicals is unfavorable for 3,4-DFCur. In addition, the absorption and penetration of inhibitors into the cell membrane are dependent on the hydrophobicity of the inhibitors. The fluorine substituent affects the physical properties of the inhibitor molecules, and aromatic fluorination increases their lipophilicity ${ }^{15}$. In the study herein, the results indicate that the lower activity of the fluorinated curcumin could be due to its increased lipophilicity.

\section{CONCLUSION}

Curcumin and 3,4-difluorinated curcumin have been completely synthesized in $53 \%$ and $72 \%$ yields from condensation reactions between benzaldehyde analogues and pentane-2,4-dione, using $\mathrm{B}_{2} \mathrm{O}_{3}$, tri- $n$ butyl borate and $n$-butylamine as complexing agent, water scavenger and basic catalyst, respectively. The moderate yields obtained from the synthetic procedures can be applied to synthesize curcumin and its derivatives since the isolation of natural curcuminoids from the Curcuma longa rhizome is a costly procedure and since organo-fluorine compounds isolated 
from plants have been virtually absent. The cytotoxicities against HepG2, LU-1 and KB cancer cell lines of the synthesized compounds were evaluated. The skeleton of the 4-hydroxy curcumin exhibited higher anticancer activities while aromatic substitutions by fluoro groups negatively impacted the anticancer activities. This was due to alterations of the electronic properties, which caused unfavorable formation of phenoxyl radicals, and the increased lipophilicity.

\section{LIST OF ABBREVIATIONS}

Cur: Curcumin

3,4-DFCur: 3,4-Difluorinated curcumin

DCM: Dichloromethane

EA: Ethyl acetate

HEX: $n$-Hexane

HepG2: Human liver cancer cell line

LU-1: Lung cancer cell line

KB: Human oral epidermal carcinoma cell line

IC $_{50}$ : Half-maximal inhibitory concentration

NMR: Nuclear magnetic resonance

TLC: Thin layer chromatography

CC: Column chromatography

MS: Mass spectrometry

\section{AUTHOR CONTRIBUTIONS}

The contributions of all authors are equal in experimental design, laboratory work-up, data analysis and manuscript preparation.

\section{COMPETING INTERESTS}

The authors declare that they have no competing interests.

\section{SUPPORTING INFORMATION}

Supporting Information contains chemicals used for synthetic procedures and purifications of eight curcumin analogues, percent inhibition (I\%) values at various concentrations and their NMR and MS spectra.

\section{ACKNOWLEDGMENT}

This work belongs to the project grant No: B2020SPK-05 funded by Ministry of Education and Training, and hosted by Ho Chi Minh City University of Technology and Education, Vietnam.

\section{REFERENCES}

1. Siegel RL, Miller KD, Jemal A. Cancer statistics, 2018: Cancer Statistics, 2018. CA Cancer J Clin . 2018;68:7-30. PMID: 29313949. Available from: https://doi.org/10.3322/caac.21442.

2. Youssef D, Nichols CE, Cameron TS, Balzarini J, De Clercq E, Jha A. Design, synthesis, and cytostatic activity of novel cyclic curcumin analogues. Bioorg Med Chem Lett. 2007;17:56245629. PMID: 17768050. Available from: https://doi.org/10. 1016/j.bmcl.2007.07.079.
3. Labbozzetta M, Baruchello R, Marchetti P, Gueli MC, Poma P, Notarbartolo M, et al. Lack of nucleophilic addition in the isoxazole and pyrazole diketone modified analogues of curcumin; implications for their antitumor and chemosensitizing activities. Chem Biol Interact. 2009;181:29-36. PMID: 19539615. Available from: https://doi.org/10.1016/j.cbi.2009.06.005.

4. Borik R, Fawzy N, Abu-Bakr S, Aly M. Design, Synthesis, Anticancer Evaluation and Docking Studies of Novel Heterocyclic Derivatives Obtained via Reactions Involving Curcumin. Molecules . 2018;23:1398. PMID: 29890691. Available from: https://doi.org/10.3390/molecules23061398.

5. Lozada-García M, Enríquez R, Ramírez-Apán T, Nieto-Camacho A, Palacios-Espinosa J, Custodio-Galván Z, et al. Synthesis of Curcuminoids and Evaluation of Their Cytotoxic and Antioxidant Properties. Molecules. 2017;22:633. PMID: 28420097. Available from: https://doi.org/10.3390/molecules22040633.

6. Tomeh M, Hadianamrei R, Zhao X. A Review of Curcumin and Its Derivatives as Anticancer Agents. Int J Mol Sci. 2019;20:1033. Available from: https://doi.org/10.3390/ ijms20051033.

7. Agrawal DK, Mishra PK. Curcumin and its analogues: Potential anticancer agents. Med Res Rev. 2009;PMID: 20027668. Available from: https://doi.org/10.1002/med.20188.

8. Anto R. Anti-tumour and free radical scavenging activity of synthetic curcuminoids. Int J Pharm. 1996;131:1-7. Available from: https://doi.org/10.1016/0378-5173(95)04254-7.

9. Bhuvaneswari K, Sivaguru P, Lalitha A. Synthesis, Biological Evaluation and Molecular Docking of Novel Curcumin Derivatives as BCl-2 Inhibitors Targeting Human Breast Cancer MCF-7 Cells. ChemistrySelect. 2017;2:11552-11560. Available from: https://doi.org/10.1002/slct.201702406.

10. Ahmed $M$, Abdul Qadir $M$, Imtiaz Shafiq $M$, Muddassar $M$, Hameed A, Nadeem Arshad M, et al. Curcumin: Synthesis optimization and in silico interaction with cyclin dependent kinase. Acta Pharm. 2017;67:385-395. PMID: 28858834. Available from: https://doi.org/10.1515/acph-2017-0023.

11. Xu G, Chu Y, Jiang N, Yang J, Li F. The Three Dimensional Quantitative Structure Activity Relationships (3D-QSAR) and Docking Studies of Curcumin Derivatives as Androgen Receptor Antagonists. Int J Mol Sci. 2012;13:6138-6155. PMID: 22754355. Available from: https://doi.org/10.3390/ ijms13056138.

12. Banuppriya G, Sribalan R, Padmini V. Evaluation of Antioxidant, Anti-Inflammatory, Antibacterial Activity and In Silico Molecular Docking Study of Pyrazole Curcumin Bisacetamide Analogues. ChemistrySelect. 2017;2:9168-9173. Available from: https://doi.org/10.1002/slct.201701533.

13. Pabon HJJ. A synthesis of curcumin and related compounds. Recl Trav Chim Pays-Bas. 1964;83:379-386. Available from: https://doi.org/10.1002/recl.19640830407.

14. Krackov MH, Bellis HE. Process for the synthesis of curcuminrelated compounds. US5679864A. 1997;

15. Smart BE. Fluorine substituent effects (on bioactivity). J Fluor Chem. 2001;109:3-11. Available from: https://doi.org/10.1016/ S0022-1139(01)00375-X.

16. Schlosser M, Michel D. About the "physiological size" of fluorine substituents: Comparison of sensorially active compounds with fluorine and methyl substituted analogues. Tetrahedron. 1996;52:99-108. Available from: https://doi.org/ 10.1016/0040-4020(95)00886-D.

17. Mosmann T. Rapid colorimetric assay for cellular growth and survival: Application to proliferation and cytotoxicity assays. $\mathrm{J}$ Immunol Methods. 1983;65:55-63. Available from: https:// doi.org/10.1016/0022-1759(83)90303-4.

18. Scudiero DA, Shoemaker RH, Paull KD, Monks A, Tierney $\mathrm{S}$, Nofziger $\mathrm{TH}$, et al. Evaluation of a soluble tetrazolium/formazan assay for cell growth and drug sensitivity in culture using human and other tumor cell lines. Cancer Res. 1988;48:4827-4833. 
19. Malacrida A, Cavalloro V, Martino E, Cassetti A, Nicolini G, Rigolio R, et al. Anti-Multiple Myeloma Potential of Secondary Metabolites from Hibiscus sabdariffa. Molecules. 2019;24:2500. Available from: https://doi.org/10.3390/ molecules24132500.

20. Awasthi S, Pandya U, Singhal SS, Lin JT, Thiviyanathan V, Seifert WE, et al. Curcumin-glutathione interactions and the role of human glutathione S-transferase P1-1. Chem Biol Interact. 2000;128:19-38. Available from: https://doi.org/10.1016/ S0009-2797(00)00185-X.

21. Dinkova-Kostova AT, Talalay P. Relation of structure of curcumin analogues to their potencies as inducers of Phase 2 detoxification enzymes. Carcinogenesis. 1999;20:911-914. PMID: 10334211. Available from: https://doi.org/10.1093/ carcin/20.5.911.

22. Gutteridge JMC, Halliwell B. Free Radicals and Antioxidants in the Year 2000: A Historical Look to the Future. Ann N Y Acad Sci. 2006;899:136-147. PMID: 10863535. Available from: https: //doi.org/10.1111/j.1749-6632.2000.tb06182.x.

23. Sökmen $M$, Akram Khan $M$. The antioxidant activity of some curcuminoids and chalcones. Inflammopharmacology. 2016;p. 81-86. PMID: 27188988. Available from: https://doi. org/10.1007/s10787-016-0264-5.

24. Mishra S, Kapoor N, Mubarak Ali A, Pardhasaradhi BVV, Kumari $\mathrm{AL}$, Khar A, et al. Differential apoptotic and redox regulatory activities of curcumin and its derivatives. Free Radic Biol Med. 2005;38:1353-1360. PMID: 15855053. Available from: https: //doi.org/10.1016/j.freeradbiomed.2005.01.022. 